\title{
A korai kéttannyelvű oktatás hatása a kisiskolások anyanyelvi szövegértési és helyesírási kompetenciájára
}

\author{
Szaszkó Rita - Jezsik Kata \\ Szent István Egyetem Alkalmazott Bölcsészeti és Pedagógiai Kar, Jászberény
}

\begin{abstract}
A korai két tanítási nyelvü oktatási programokban résztvevö kisgyermekek szüleiben gyakran felmerül a kérdés, vajon e speciális iskolai képzés milyen hatással van gyermekeik anyanyelvi szövegértési és helyesírási kompetenciájára. E kérdésre irányuló vizsgálatunkban egy észak-alföldi kéttannyelvü általános iskola két 2. osztálya ( $N=59)$ vett részt: a magyar-angol két tanítási nyelvü programban tanuló kísérleti csoport $(n=34)$, és a kontrollcsoport ( $n=25)$, akiknek minden tantárgy oktatása magyarul zajlik. Kutatóeszközként egy a korosztály számára kidolgozott magyar nyelvü szövegértési és kompetenciatesztet használtunk. Kutatásunk hipotézise igazolást nyert, azaz az angol-magyar két tanítási nyelvü programban tanuló 2. osztályos kisiskolás gyermekek anyanyelvi szövegértési és helyesirási készségei nem maradnak el a hagyományos monolingvális magyar nyelvü tanítási programban szereplö kortársaikétól, a kétnyelvü oktatás nem hat negatívan anyanyelvi kompetenciáik fejlödésére.
\end{abstract}

Kulcsszavak: két tanitási nyelvü oktatás, 2. osztály, anyanyelvi, szövegértési kompetencia, helyesirás

\section{Bevezetés}

A kéttanyelvű általános iskolai nyelvtanulási programok iránt nagy a szülői érdeklődés, mivel az ilyen típusú korai idegen nyelvi oktatás segítségével kisgyermekeik hosszabb távon versenyképesebb nyelvi tudásra és kompetenciákra tudnak szert tenni (Kovács, 2006. 106-111. o.). Azonban az általános iskolai tanulmányaik megkezdése előtt álló kisgyermekek szüleinek egyik gyakori dilemmája a két tanítási nyelvű programok esetén, hogy vajon az idegen nyelven oktatott tantárgyak nem hatnak-e negatívan a gyermekük anyanyelvi fejlődésére. Több, szülökkel folytatott informális beszélgetés során gyakran felmerült a kérdés, hogy a két tanítási nyelvű programban tanuló kisdiákok magyar nyelvi készségei, különösen az anyanyelvi olvasott szövegértési és a helyesírási kompetenciái megfelelően tudnak-e fejlődni. Ennek vizsgálatára készült egy longitudinális kutatási terv két tanítási nyelvü és anyanyelvi tanterv szerint haladó általános iskolai osztályok bevonásával a következő hipotézissel: Az angol két tanítási nyelvü programban tanuló kisiskolás gyermekek anyanyelvi szövegértési és helyesírási kompetenciái nem maradnak el a magyar nyelvü oktatási programban tanuló kortársaikétól.

E tanulmányban a longitudinális vizsgálat kiindulási pontjának, azaz az első, 2. osztályban vett mintavételének eredményei kerülnek bemutatásra. A vizsgálat relevánsnak tekinthető, mivel a magyar-angol két tanítási nyelvű oktatás hatásának vizsgálatához a magyar nyelvi és szövegértési kompetenciák tekintetében sok empirikus kutatásra, kvantitatív és kvalitatív eredményre van még szükség. Gósy (2008) hangsúlyozza, hogy a hatékony olvasástanításhoz (és szövegértés-fejlesztéshez) nélkülözhetetlenek a pszichológiai, pszicholingvisztikai, nyelvészeti és alkalmazott nyelvészeti kutatások eredményei és következtetései. Márkus (2008. 86. o.) a magyarországi német nemzetiségi iskolák 4. osztályaiban feladatlapok kitöltetésével mérte az idegen nyelvi olvasott 
szövegértési és az írásbeli kommunikációs kompetenciákat az iskolai nyelvoktatás hatékonyságának vizsgálatára. Kovács (2011) két kétnyelvű általános iskola 4. osztályosainak körében szóbeli felmérést végzett a tanulók nyelvi és nem nyelvi kompetenciái, illetve tanulási stratégiái feltérképezésére ${ }^{1}$. E tanulmányunkban bemutatott kéttannyelvü oktatásban részesülő gyermekek anyanyelvi kompetenciáinak mérése hiánypótló vizsgálatnak tekinthető, melynek eredményei informatívak mind a két tanítási nyelvü iskoláknak, a kéttannyelvű programban oktató tanítóknak, mind a szülöknek.

\section{Elméleti háttér}

\subsection{A két tanítási nyelvű programok a magyar közoktatási rendszerben}

Magyarországon az angol nyelvü általános iskolai oktatási programok kialakulásának kezdete az 1980-as évek végére tehető, melynek alakulására hatással voltak az 1985ös, 1989-es és 1997-es oktatáspolitikai rendelkezések, amelyek lehetővé tették az alsó fokú oktatási intézmények számára a szabad idegen nyelvi kínálatot és profilkialakítást (Kovács, 2005. 87-88, 92. o.). Kovács (2005) empirikus kutatása kimutatta, hogy az 1996-1997-es tanévben 9 (0,24\%) kétnyelvű program volt az alsó fokú oktatásban 1.597 diákkal, míg a 2002-2003-as időszakban 56 két tanítási nyelvü programban már 10.528 gyermek tanult. 2008-ra közel 90 általános iskolában müködött két tanítási nyelvủ program (Kovács, 2009. 100. o.). A legtöbb kétnyelvű program magyar-angol nyelvű, az angol lingua franca szerepének köszönhetően; ebből is következik, hogy a magyarangol két tanítási nyelvü általános iskolai programokban tanulók száma már 3.534 volt 1998-ban (Kovács, 2005). Az eredmények alapján elmondható, hogy Magyarországon a két tanítási nyelvű korai nyelvoktatás területén az általános iskolákban növekvő tendencia tapasztalható. A magyar-angol két tanítási nyelvű alsó fokú oktatásban az angol nyelvű oktatás óraszáma heti minimum nyolc óra már első osztályban. Plusz értéket jelent e program esetében, hogy a magyar anyanyelvủ angoltanító munkáját angol anyanyelvü pedagógus is segíti. Továbbá, a nyelvi órákon kívül, bizonyos tantárgyak tartalmának tanítása is angol nyelven történik már a kezdetektől (Kovács, 2006. 71-72, 112. o.). Mindezek egyik fontos üzenete, hogy a korai két tanítási nyelvű pedagógusképzés prioritást kívánó feladat, és a kétnyelvű tanítók és pedagógusjelöltek nézeteinek, szükségleteinek, problémáinak vizsgálata kulcsfontosságú (Trentinné, 2009, 2013).

\subsection{Szövegértési kompetencia}

A szövegértési kompetencia a szövegbe kódolt üzenet rekonstruálásának készségeként definiálható (N. Császi, 2009). A gyermekek olvasott szövegértését folyamatosan fejleszteni kell, beleértve a kritikai és a kreatív olvasási képességeket. A pedagógusok számára a kisdiákok anyanyelvi olvasott szövegértési kompetenciájának fejlesztése nem csak a részkompetenciák fejlesztését jelenti. Ide tartozik a tanulók olvasási stratégiaválasztási képességének és egyéb metakognitív kompetenciáiknak a fejlesztése is. Ezekhez a kritériumokhoz illeszkedve a magyar közoktatásban az 1989 utáni olvasástanítási programokban nagyobb hangsúlyt kap a szövegértést segítő szemléltetés az olvasási nehézségek leküzdésére (Gósy, 2008). Az olvasási megértési deficitek különböző hiányosságokból fakadhatnak: 1. szóolvasási nehézség (hosszú, fárasztó

\footnotetext{
1 http://old.tok.elte.hu/kutatokozpont/upload/kutatomuhely_idny_2013.pdf
} 
A korai kéttannyelvű oktatás hatása a kisiskolások anyanyelvi szövegértési és helyesírási kompetenciájára

szó kibetűzése), 2. hiányos szókincs és/vagy háttérismeret (sémaismeret, kulturális ismeretek stb. hiánya), 3. következtetés képességének fejletlensége, 4. nagyszámú ismeretlen elem az adott szövegrészben és 5. bonyolult, összetett nyelvtani szerkezetek (például többszörösen összetett mondatok) (Lackó, 2008; N. Császi, 2009). Ezen szövegértési elakadást okozó elemeket a részképességek fejlesztésével lehet kiküszöbölni, azok fokozatosan integrált egymáshoz kapcsolásával (N. Császi, 2009).

Gósy (2009) gyermekek anyanyelvi kompetenciáit vizsgáló empirikus kutatása kimutatta, hogy hatéves kor alatt a szöveg feldolgozását föként a részletek mozaikos összerakása jelenti, míg hat éves kor fölött és felnőtteknél a holisztikusabb megértés alakul ki, azaz a különféle összefüggéseket meglátják, még akkor is, ha egy adott részlet nem pontosan jelenik meg emlékezetükben. Tehát a szövegértési kompetencia fejlődése eltolódást jelent a részletek mozaikszerü felismerésétől az összefüggések megértése irányába. E fejlődési folyamat gyakori gátló tényezői lehetnek: 1. az észlelési zavar, 2. a lexikális hiányosságok, 3. a morfológiai bizonytalanság, 4. a szintaktikai bizonytalanság, 5. a memorizációs nehézségek, 6 . az asszociációs problémák, valamint 7 . a lassúság. Gósy tanulmánya szerint a hétéves korosztály szövegértésére jellemző a legszembetünőbb individuális variancia, melyre hatással lehet az iskolakezdés. Továbbá, Gósy jelentős fejlődést mutatott ki a vizsgált nyolcéveseknél, és valamivel kisebb ütemű szövegértési fejlődést a kilencéveseknél. Ezen eredmények is alátámasztják, hogy a szövegértési kompetencia nem mutat lineáris fejlődést az életkor tekintetében.

\subsection{Anyanyelvi helyesírási kompetencia}

A magyar nyelvi helyesírásikompetencia-fejlesztés magában foglalja a helyesírási szabályok megismertetését és azok alkalmazásának képességét, a helyesírási példák rögzítését, helyesírás-fejlesztési stratégiák elsajátítását és alkalmazását, valamint a helyesírást ellenőrző papíralapú és elektronikus, on-line eszközök használatát (Antalné, 2010). A jelenkori magyar oktatási rendszerben a rendszerszemléletű helyesírás-tanítás elve szerint történik a fejlesztés különféle vizuális eszközökkel segítve (például helyesírási táblázatok és fürtábrák). A helyesírási szabályok elsajátításának kognitív módjai például a következők: 1. felfedező feladatra épülő ismeretelsajátítás, 2. szemléltetésre épülő ismeretelsajátítás, 3. tanári vagy tanulói előadásra és magyarázatra épülő ismeretelsajátítás és 4. kooperatív tanulásra épülő ismeretelsajátítás (Antalné, 2010).

Empirikus kutatások igazolják, hogy a helyes íráskép bevésése akkor a legeredményesebb, ha különféle csoportmunkákban (például párban tanulás) folyik a gyakorlás minél több érzékszervi hatásra építve, és valamilyen cselekvéssel kísérve (például párkereső, színkereső, szaladgáló/sétáló feladatok). Ezekhez a kritériumokhoz illeszkedő bevéső feladattípusok lehetnek: 1. szavak kiegészítése begyakorolt hívószóval, 2. saját hívószó alkotása, 3. humoros felidéző mondat, 4. emlékezetből írás és 5. felidéző kép/illusztráció. A magyar nyelvi helyesírás hatékony elsajátításához szükséges továbbá a tanulás kontextusa, a motiváló és oldott hangulatú osztálytermi légkör, a megfelelő mennyiségü célszó és a gyakorlás jól megtervezett időbeli eloszlása (Adamikné, 2001. 249. o.; Kovácsné, 2006. 43. o.; Antalné, 2008).

\section{Kutatás}

\subsection{A résztvevők}

Jelen felmérésünk, amely egy longitudinális vizsgálat legelső fázisa, egy kelet-magyarországi magyar-angol kéttannyelvű általános iskolára fókuszál. Ebben a kutatásban 
a vizsgálat célcsoportja a 2. osztályos korcsoport, mivel ők a mintavétel időpontjában már második éve vesznek részt a két tanítási nyelvű programban, és túlvannak az iskolakezdés bevezető szakaszán.

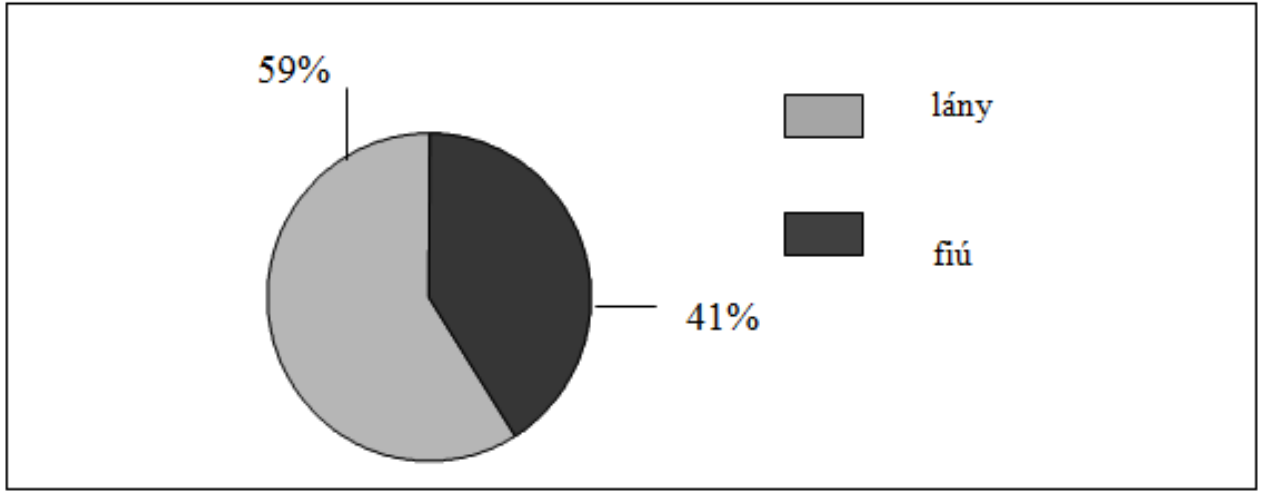

1. ábra: A kísérleti csoport ( $n=34)$ tagjainak nemek szerinti megoszlása

\begin{tabular}{|l|c|c|c|c|c|}
\hline & Testnevelés & $\begin{array}{c}\text { Rajz és } \\
\text { vizuális } \\
\text { nevelés }\end{array}$ & Ének-zene & $\begin{array}{c}\text { Életvitel és } \\
\text { gyakorlati } \\
\text { ismeretek }\end{array}$ & Angol \\
\hline $\begin{array}{l}\text { 1. osztályos } \\
\text { heti óraszám }\end{array}$ & 5 & - & 1 & 1 & $4+1$ \\
\hline $\begin{array}{l}\text { 2. osztályos } \\
\text { heti óraszám }\end{array}$ & 5 & 1,5 & 1 & - & $4+1$ \\
\hline
\end{tabular}

1. táblázat: A kísérleti csoport $(n=34)$ heti angol nyelvü óráinak száma

E tanulmányunkban a kísérleti csoport a 2. osztályos magyar-angol kéttannyelvű csoport ( $n=34)$, amelynek 59\%-a lány és 41\%-a fiú (1. ábra). Az 1. táblázatban látható, hogy a kísérleti csoportnak az 1. és a 2. tanévben is heti öt angol nyelvű testnevelés órája van. Az angol nyelvű rajz és vizuális nevelés tantárgy 2. osztályban lép be heti egy óraszámban az első félévben és heti kettőben a második félévben. Továbbá, az 1. osztály óta heti egy órában tanulják az angol nyelvű ének-zene tárgyat. Az életvitel és gyakorlati ismeretek tanítása csak 1. osztályban folyt angol nyelven, heti egy óraszámban. A kísérleti csoportnak heti négy angol órája van magyar angoltanító vezetésével, mely kiegészül heti egy anyanyelvi lektori órával.

A kontrollcsoportot az egynyelvü, magyar tanmenet szerint haladó 2. osztály $(n=25)$ alkotja, amelyben fordítottan arányos a nemek száma, mivel a kisdiákok 32\%-a lány és 68\%-a fiú (2. ábra).

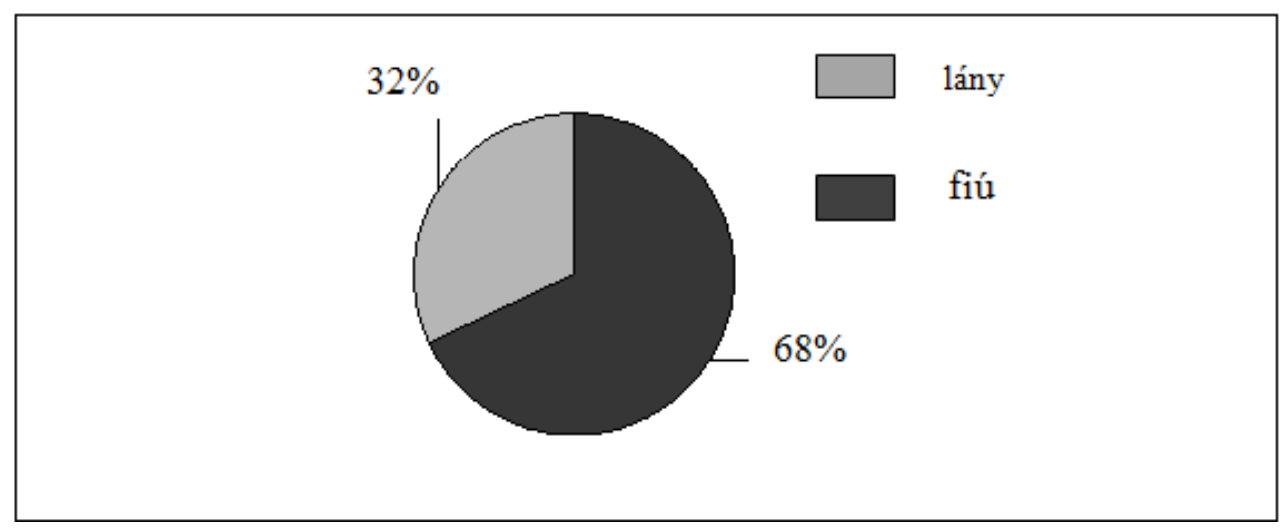

2. ábra: A kontrollcsoport tagjainak $(n=25)$ nemek szerinti megoszlása 


\subsection{A kutatóeszközök}

Akutatáshoza szakirodalom alapján összeállított kísérleti, magyar olvasottszövegértésikompetencia-teszt, illetve helyesírási diktálási szöveg szolgált elsődleges adatgyűjtő eszközként. A magyar nyelvi szövegértésikompetencia-teszt kilenc feladatból állt. A feladatok típusai a korcsoporthoz és a sztenderd kompetenciatesztekben használatos feladatok követelményeihez illeszkednek. Annyiban speciális a feladatsor, hogy nagyobb hangsúlyt kapnak az angol nyelven oktatott tárgyak (lásd 1. táblázat) témakörei és szókincse. A teszt első része a készségtárgyak tanulása során előforduló tárgyak, élőlények felismerését célozta meg. A gyermekeknek képek alapján egy táblázatban található szóhalmazból kellett kiválasztani, majd a jelentést ábrázoló kép alá beírni a helyes szót. A teszt második része egy rövid állatmesére épült, melyhez egy szövegértési feladatsor csatlakozott. A történethez kapcsolódóan a gyerekeknek a helyszínt és a szereplőket kellett megállapítaniuk, és megadott vonalra kiírniuk a megfelelő válaszokat. Ezután a kisdiákoknak az elsődleges megértést ellenőrző kérdésekre kellett a helyes megoldást megjelölniük feleletválasztós kérdésekben. Szintén az elsődleges megértést mérte a negyedik feladat, melyben egy-egy szóval kellett a kérdésekre felelni. Ezután sorrendiség helyes felállítását mérte a feladatsor, melyben a meséből vett egy-egy mondatot kellett számozással helyes sorrendbe állítani. A következő feladat a 2. osztályosok szókincsének gazdagságát mérte a meséből vett öt kifejezés segítségével. Ezek a kifejezések az első oszlopban voltak feltüntetve, a mellette lévő oszlopban pedig egy-egy szinonima volt, melyeket a gyermekeknek össze kellett társítani. A hetedik feladat a szereplők tulajdonságainak beazonosítására épült; nyolc tulajdonságot kellett két szereplő szerint szétválogatni, és a számokat a megfelelő helyre beírni. Az utolsó feladatban négyből két szólást kellett aláhúzniuk a tanulóknak, melyeket a meséhez legjobban illőnek tartottak. A helyesírási készségek ellenőrzésére az ének-zene tantárgyhoz kötődő 40 szóból álló szövegrész került lediktálásra, mely zeneszerzőkről, és a komolyzene pozitív hatásairól szólt. Másodlagos kutatóeszközként a 2012-2013as tanév első és második félévében megírt magyar olvasott szövegértési feladatsort, pontosabban annak a kísérleti és a kontrollcsoportban kapott átlageredményeit használtuk fel összehasonlítási alapként.

\subsection{A kutatás folyamata}

A mintavételhez használt kísérleti kompetenciateszt megíratása és javítása mindkét 2. osztályban egy délelőtti, órarend szerinti 45 perces tanórán 2013 májusában történt. A kompetenciateszt eredményeinek értékelése százalékos bontásban a következő volt: $100-90 \%=5,89-80 \%=4,79-70 \%=3,69-50 \%=2,49 \%-0 \%=1$. A 14 perces tollbamondás felmérése szintén egy délelőtti tanórán volt mindkét osztályban, májusban, három nappal a kísérleti kompetenciateszt megíratása után. Az értékelési skála a hibaszámok alapján a következő tartományok szerint volt felosztva: $0-5$ hiba $(h)=5,6-10 \mathrm{~h}=$ $4,11-16 \mathrm{~h}=3,17-22 \mathrm{~h}=2,23<\mathrm{h}=1$.

A kvantitatív adatok, azaz a 2012-2013-as tanév első és második félévében megírt magyar nyelvi olvasottszövegértési-kompetenciatesztek, a kísérleti kompetencia-feladatsor eredményei, illetve a tollbamondás eredményeinek feldolgozása SPSS 11.0 for Windows programmal történt. E tanulmányban a leíró statisztikai elemzések (átlag, szórás) eredményei kerülnek bemutatásra. 


\section{Eredmények}

\begin{tabular}{|l|c|c|c|c|c|}
\hline & N & $\begin{array}{c}\text { Minimum } \\
\text { (érdemjegy) }\end{array}$ & $\begin{array}{c}\text { Maximum } \\
\text { (érdemjegy) }\end{array}$ & $\begin{array}{c}\text { Átlag } \\
\text { (érdemjegy) }\end{array}$ & SD \\
\hline $\begin{array}{l}\text { Kísérleti } \\
\text { csoport }\end{array}$ & 34 & 1 & 5 & 4,29 & 1,11 \\
\hline $\begin{array}{l}\text { Kontroll- } \\
\text { csoport }\end{array}$ & 25 & 1 & 5 & 3,68 & 1,43 \\
\hline
\end{tabular}

2. táblázat: A kísérleti és a kontrollcsoport első magyar nyelvi szövegértési, 2. osztályos évközi eredményeinek átlaga $(N=59)^{2}$

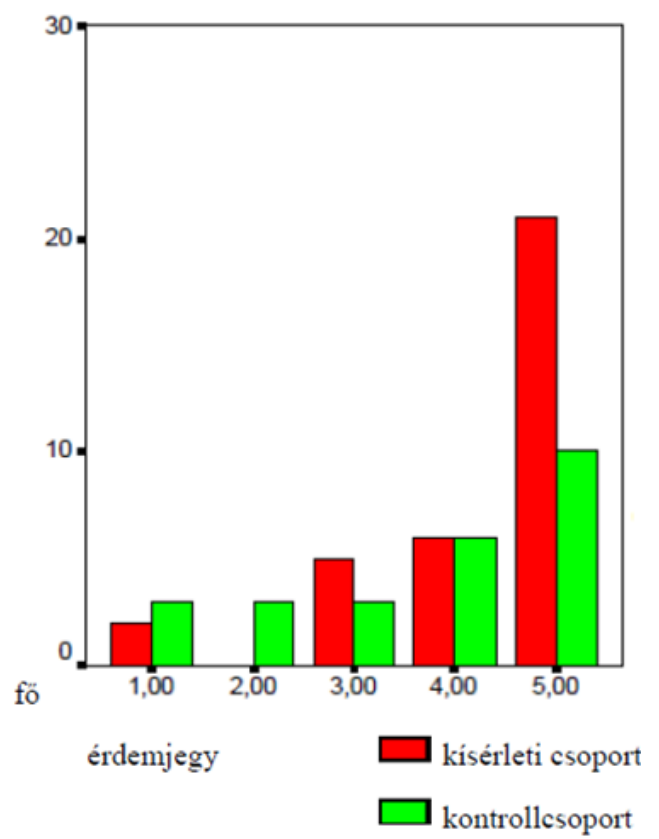

3. ábra: A kísérleti és a kontrollcsoport első magyar nyelvi szövegértési,

2. osztályos évközi eredménye ötfokú értékelési skálán $(\mathrm{N}=59)$

A 2. osztályban megírt első anyanyelvi kompetenciateszt értékelésénél mind a kísérleti, mind a kontrollcsoportban született elégtelen és jeles osztályzat, azonban a kísérleti csoport 4,29-es átlaga 0,61-kal jobb, mint a kontrollcsoport 3,68 értékü eredménye (2. táblázat). A 3. ábrán látható, hogy a kísérleti csoportban kevesebb elégtelen született, több a közepes, és kétszeres a jelesek aránya. A kísérleti csoportban elégséges érdemjegy nem volt, illetve mindkét csoportban azonos volt a jó érdemjegyek megoszlása.

\begin{tabular}{|l|c|c|c|c|c|}
\hline & N & $\begin{array}{c}\text { Minimum } \\
\text { (érdemjegy) }\end{array}$ & $\begin{array}{c}\text { Maximum } \\
\text { (érdemjegy) }\end{array}$ & $\begin{array}{c}\text { Átlag } \\
\text { (érdemjegy) }\end{array}$ & SD \\
\hline $\begin{array}{l}\text { Kísérleti } \\
\text { csoport }\end{array}$ & 34 & 3 & 5 & 4,56 & 0,66 \\
\hline $\begin{array}{l}\text { Kontroll- } \\
\text { csoport }\end{array}$ & 25 & 2 & 5 & 4,08 & 0,86 \\
\hline
\end{tabular}

3. táblázat: A kísérleti és a kontrollcsoport második magyar nyelvi szövegértési,

2. osztályos évközi eredményeinek átlaga $(\mathrm{N}=59)^{3}$

\footnotetext{
2 Megjegyzés: elégtelen (1), jeles (5).

${ }^{3}$ Megjegyzés: elégtelen (1), jeles (5).
} 


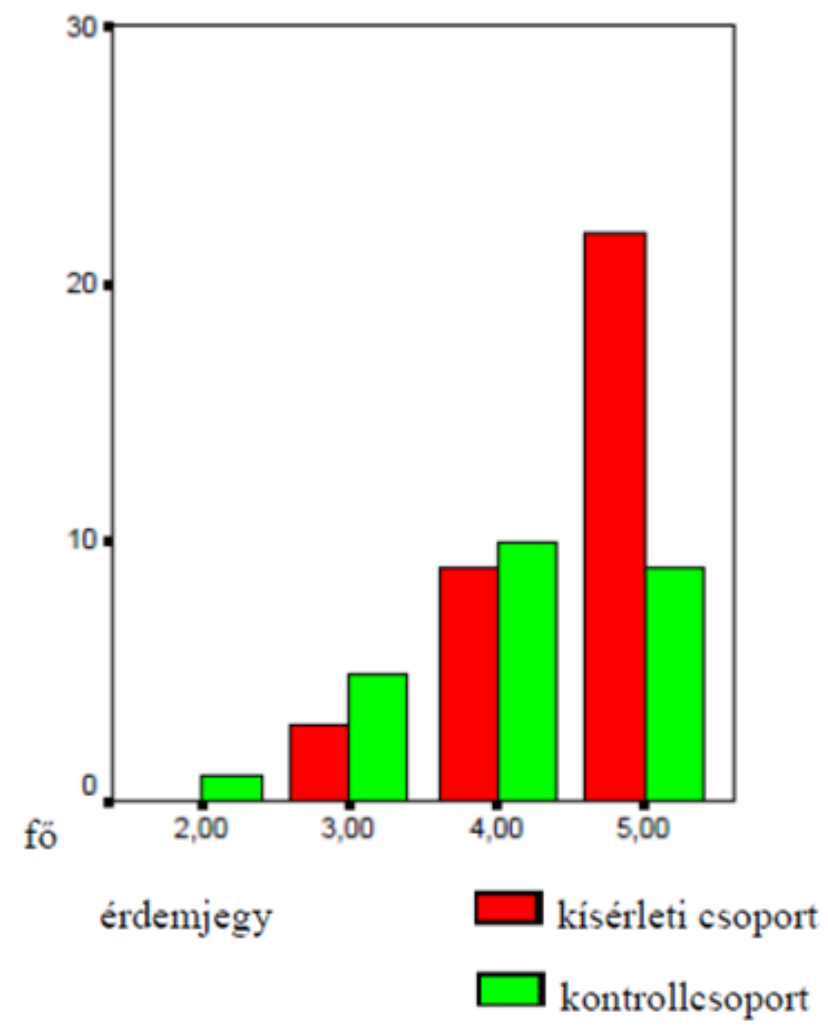

4. ábra: A kísérleti és a kontrollcsoport második magyar nyelvi szövegértési,

2. osztályos évközi eredménye $(\mathrm{N}=59)$

A második évközi magyar szövegértési eredmények hasonló tendenciát mutatnak, mint az első évközi szövegértési feladatsor eredményei, azonban a két csoport összesített átlaga között kisebb $(0,19)$ az eltérés (3. táblázat). Elégtelen nem született egyik osztályban sem, elégséges csak a kontrollcsoportban. Több érdemjegy esett a közepes és jó tartományba a kontrollcsoport esetében, valamint több, mint kétszeres a jeles osztályzatok aránya a kísérleti csoportban (4. ábra).

\begin{tabular}{|l|c|c|c|c|c|}
\hline & $\mathbf{N}$ & $\begin{array}{c}\text { Minimum } \\
(\%)\end{array}$ & $\begin{array}{c}\text { Maximum } \\
(\%)\end{array}$ & $\begin{array}{c}\text { Átlag } \\
(\%)\end{array}$ & SD \\
\hline $\begin{array}{l}\text { Kísérleti } \\
\text { csoport }\end{array}$ & 34 & 59 & 100 & 89,68 & 10,25 \\
\hline $\begin{array}{l}\text { Kontroll- } \\
\text { csoport }\end{array}$ & 25 & 17 & 100 & 59,40 & 26,51 \\
\hline
\end{tabular}

4. táblázat. A kísérleti és kontrollcsoport kísérleti kompetenciateszt-eredményeinek átlaga ( $N=59)$ 


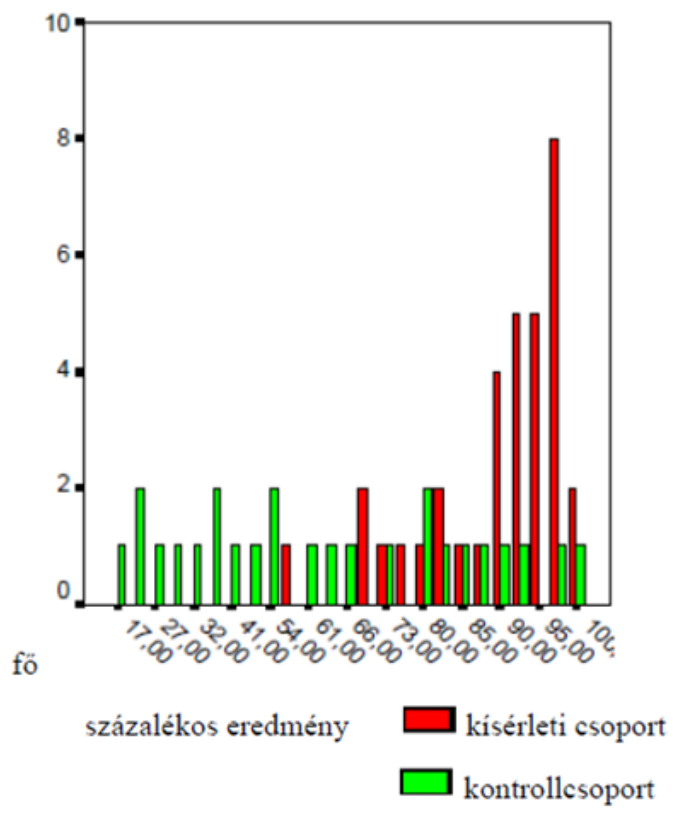

5. ábra: A kísérleti és a kontrollcsoport kísérleti magyarnyelvi-kompetenciateszt eredménye ( $N=59)$

A 4. táblázat mutatja, hogy 30,28\%-os eltérés van a két csoport százalékos eredményének átlagát illetően a kísérleti csoport javára $(89,68 \%)$, és a szórás is kisebb mértékű ennél az osztálynál (SD 10.25). Az 5. ábra jelzi, hogy az 59\%-os tartományig csak a kontrollcsoport eredményei jelennek meg, 90\%-tól a kísérleti csoport eredményei kiugróak, és mindkét csoportban született 100\%-os eredmény.

\begin{tabular}{|l|c|c|c|c|c|}
\hline & N & $\begin{array}{c}\text { Minimum } \\
\text { (hibaszám) }\end{array}$ & $\begin{array}{c}\text { Maximum } \\
\text { (hibaszám) }\end{array}$ & $\begin{array}{c}\text { Átlag } \\
\text { (hibaszám) }\end{array}$ & SD \\
\hline $\begin{array}{l}\text { Kísérleti } \\
\text { csoport }\end{array}$ & 34 & 1 & 21 & 5,66 & 4,87 \\
\hline $\begin{array}{l}\text { Kontroll- } \\
\text { csoport }\end{array}$ & 25 & 0 & 25 & 7,52 & 6,29 \\
\hline
\end{tabular}

5. táblázat. A kísérleti és kontrollcsoport tollbamondás-eredményeinek átlaga ( $N=59)$

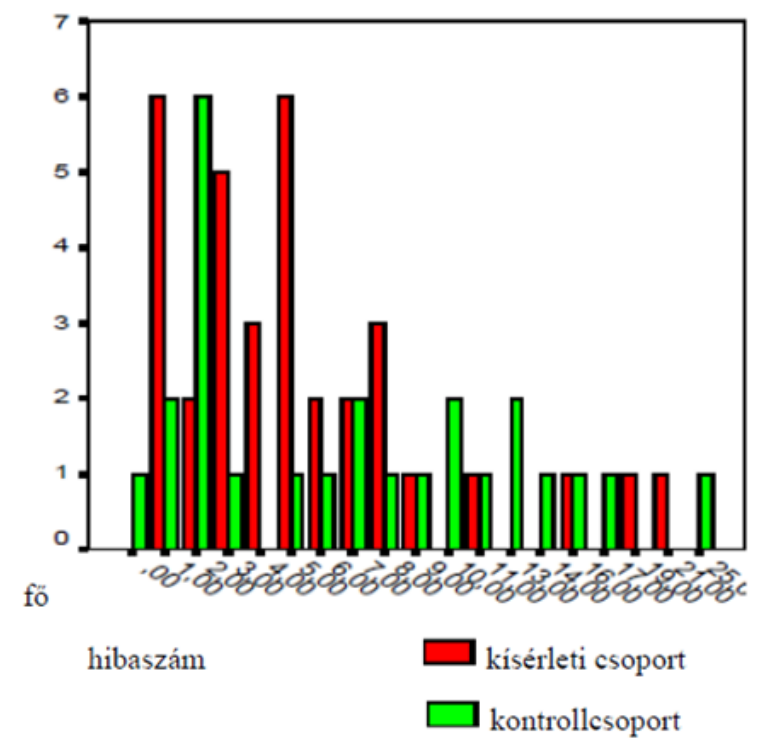

6. ábra: Helyesírási hibaszámok. A kísérleti és a kontrollcsoport tollbamondásos helyesírási mérésének eredménye $(\mathrm{N}=59)$ 
A korai kéttannyelvủ oktatás hatása a kisiskolások anyanyelvi szövegértési és helyesírási kompetenciájára

A magyar nyelvi tollbamondásos helyesírási felmérés legkevesebb hibaszáma egy volt a kísérleti csoportnál, míg a kontrollcsoportnál volt hibátlan helyesírással megírt szöveg. Azonban a kísérleti csoport maximum hibaszáma 4 hibával, valamint az átlag hibaszáma 1,86 hibával alacsonyabb volt, mint a kontrollcsoporté. Az 1-8 hibaszámú tartományban a kísérleti csoport alacsonyabb hibaszámai kiugróan jobb eredményt mutatnak a kontrollcsoport eredményeihez képest.

\section{4. Összegzés}

A gyermeküket két tanítási nyelvű programba beírató szülők egyik gyakori aggálya, hogy vajon a korai két tanítási nyelvủ általános iskolai oktatás nem hat-e károsan gyermekük anyanyelvi szövegértési és helyesírási kompetenciáira. E problémafelvetés vizsgálatára készült el egy longitudinális vizsgálat első tanulmánya egy magyar-angol kéttannyelvű általános iskolában 59 másodikos kisdiák bevonásával. A speciálisan összeállított hétéves korosztálynak megfelelő kísérleti magyar szövegértési feladatsor, illetve tollbamondás eredményeinek leíró statisztikai (átlag, szórás) adatai azt jelezték, hogy a 34 tanulóból álló két tanítási nyelvű programban résztvevő 2. osztályos kísérleti csoport eredményei mind a négy felhasznált mérőeszközzel (első és második évközi magyar olvasottszövegértési-kompetenciateszt, kísérleti magyar olvasott szövegértési és helyesírási teszt) jobb eredményt mutatnak a 25 főből álló kontrollcsoport eredményeinél. Tehát e kutatás hipotézise igazolást nyert, azaz az angol-magyar két tanítási nyelvü programban tanuló 2 . osztályos kisiskolás gyermekek anyanyelvi szövegértési és helyesírási készsége nem marad el a hagyományos monolingvális magyar nyelvű tanítási programban szereplő kortársaikétól, a kétnyelvű oktatás nem hat negatívan anyanyelvi kompetenciáik fejlődésére. Ez az eredmény illeszkedik Slavin és Cheung (2004) eredményeihez, akik azt találták, hogy a két tanítási nyelvű programok nem hatnak károsan, ellenkezőleg, általában fejlesztik az adott programban résztvevő angolnyelv-tanulók olvasási készségeit. Azok a tanulók, akik mind anyanyelvükön, mint angolul tanulnak olvasni, jobban teljesítették az olvasottszövegértési-tesztet, mint a csak angol nyelvű programban tanuló társaik. Továbbá, tanulmányunkban a résztvevő kéttannyelvű oktatási programban tanuló 2. osztályos kisdiákok szisztematikusan jobb eredményeket produkáltak a magyar nyelvi olvasottszövegértési- és helyesírási kompetenciák terén. Hangsúlyozottan ki kell emelni, hogy ezek az eredmények leíró jellegüek, a vizsgált két tanítási nyelvü általános iskola 2. évfolyamára igazak, nagyobb általánosítás nem vonható le belőlük. Fontosnak tartjuk kiemelni, hogy a kísérleti csoport jobb eredménye számos faktor összetett hatása lehet (intenzívebb tanulói motivációval rendelkező gyermekek, tankönyv, tanító, órarend stb.), melynek további vizsgálata hasznos következtetésekkel szolgálhat. E változók és azok korrelációinak feltérképezése vizsgálatunk részét képezi.

A longitudinális felmérésünk első vizsgálatának legföbb további célja nyomon követni a most vizsgált 2 . osztályos gyermekek anyanyelvi szövegértési és helyesírási kompetenciáinak fejlődését. További kutatási cél minden tanévben az újonnan belépő 1. osztályosok bevonása a vizsgálatba, és ezzel a minta növelése. A kutatási terv szerint a longitudinális vizsgálat negyedik évétől a megnövekedtet mintaszám alapján általános következtetések is levonhatóak. Továbbá, a kvantitatív adatok mellett szülőktől, tanítóktól kapott kvalitatív adatok begyüjtése szükséges, hogy a statisztikai számszaki adatok mellett mélyebb, személyesebb betekintést kaphassunk a szülői és tanítói véleményekről és attitüdökről a két tanítási nyelvủ általános iskolai programban résztvevő gyermekek magyar nyelvi kompetenciáinak fejlődése/fejlesztése tekintetében. 


\section{Felhasznált irodalom}

Adamikné Jászó Anna (2001): Anyanyelvi nevelés az ábécétől az érettségiig. Trezor Kiadó: Budapest.

Antalné Szabó Ágnes (2008). A helyesírási kultúra fejlesztésének régi-új technikái. Anyanyelv-pedagógia, 3-4.

URL: http://www.anyanyelv-pedagogia.hu/cikkek.php?id=109. Letöltés ideje: 2013. 03. 27.

Antalné Szabó Ágnes (2010): A magyar helyesírás vizuális rendszere. Anyanyelv-pedagógia, 4. URL: http://www.anyanyelv-pedagogia.hu/cikkek.php?id=286. Letöltés ideje: 2013. 03. 27.

Gósy Mária (2008): A szövegértő olvasás. Anyanyelv-pedagógia, 1.

URL: http://www.anyanyelv-pedagogia.hu/cikkek.php?id=25. Letöltés ideje: 2013. 03. 27.

Gósy Mária (2009): Gyermekek anyanyelvi kompetenciájáról. Gyógypedagógiai Szemle, 1-2. URL: http://prae.hu/prae/gyosze.php?menu_id=102\&jid=24\&jaid=310. Letöltés ideje: 2013. 03. 27.

Kovács, Judit (2005): Primary Bilingual Programmes in Hungarian Public Education: a summary.

URL: http://www.kettannyelvu.com/public/kovacs, \%20judit \%20-\%20primary\%20 bilingual\%20programmes\%20in\%20hungary\%20-\%20a\%20\%20summary.doc. Letöltés ideje: 2013. 03. 21.

Kovács Judit (2006): Magyar-angol kéttannyelvü általános iskolai programok közoktatásunkban. Eötvös József Könyvkiadó: Budapest.

Kovács Judit (2009): Könyvszemle: Vámos Ágnes: A kéttannyelvü oktatás tannyelv-politikai problématörténete és jelenkora. Modern Nyelvoktatás, 15. 1-2., 100-103.

Kovács Judit (2011): A hazai korai kétnyelvü/kéttannyelvü programok kutatómühelye. URL: http://www.tofk.elte.hu/kutatokozpont/node/50. Letöltés ideje: 2013. 03. 23.

Kovácsné Sipos Márta (2006): A tanulás fortélyai. Nemzeti Tankönyvkiadó, Budapest.

Lackó Mária (2008): Anyanyelvi szövegértés és grammatikai tudás. Új Pedagógiai Szemle, 58. 1-2.

URL: http://epa.oszk.hu/00000/00035/00120/2008-01-ta-Laczko-Anyanyelvi.html. Letöltés ideje: 2013. 03. 25.

Márkus Éva (2008): Az iskolai nyelvoktatás hatékonyságának vizsgálata a magyarországi német nemzetiség iskoláiban. Modern Nyelvoktatás, 15. 1-2., 85-108.

N. Császi Ildikó (2009): Szövegértést fejlesztő gyakorlatok az anyanyelvi kommunikáció kulcskompetencia fejlesztéséhez. Anyanyelv-pedagógia, 3.

URL: http://www.anyanyelv-pedagogia.hu/cikkek.php?id=197

Slavin, R. E. és Cheung, A. (2004): How Do English Language Learners Learn to Read?. What Research Says About Reading, 61. 6., 52-57.

URL: http://www.ascd.org/ASCD/pdf/journals/ed_lead/el200403_slavin.pdf. Letöltés ideje: 2015.12.23.

Trentinné Benkő Éva (2009): Az „ideális” kéttannyelvű tanár - ahogy a pedagógusok látják. In: Kovács Judit és Márkus Éva (szerk.), Kéttannyelvüség - Pedagógusképzés, kutatás, oktatás. ELTE Eötvös Kiadó, Budapest, 143-158.

Trentinné Benkő Éva (2013): Kétnyelvi pedagógusképzésben részt vevő hallgatók nézeteinek megjelenése kreatív vizuális alkotásaikban. Gyermeknevelés, 1. 1. sz., 73-105. 